\title{
Utility of multivariate statistical analysis to identify factors contributing river water quality in two different seasons in cold-arid high-altitude region of Leh-Ladakh, India
}

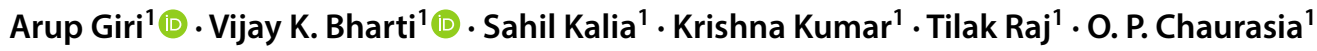

Received: 11 October 2018 / Accepted: 18 January 2019 / Published online: 9 February 2019

(C) The Author(s) 2019

\begin{abstract}
Monitoring water quality of surface water resources is the key concern in determining the potable water quality in highaltitude region. Therefore, there is a need to evaluate different parameters affecting water quality of river and identify the most important variables and factors significantly affecting water quality. In the present study, multivariate statistical methods including cluster analysis and principal component analysis/factor analysis were applied to analyze the Indus River water quality in the Trans-Himalayan region of India. For this total 25 no. of physicochemical parameters were analyzed in water samples taken from seven different monitoring sites in summer and winter season. All the physical, microbial, chemical, and mineral parameters were analyzed by using the standard methods of American Public Health Association, whereas minerals were determined with the inductively coupled plasma optical emission of spectroscopy method. Thereafter, experimental two-season ( 28 samples $\times 25$ parameters) matrices of both the seasons were run through the multivariate statistical data analysis. The varifactors obtained from the FA of both the seasons and results indicate that the parameters responsible for water quality variations are mainly related to discharge and temperature (natural), organic pollution (point source: domestic sanitary waste), and nutrients (non-point sources: agriculture) in the summer season. However, in the winter seasons, results showed that the river water was less affected by anthropogenic activities and natural weathering process. Therefore, it is concluded that quality of Indus River water is affected by agricultural, domestic, and hydrogeochemical sources in the summer season. These findings corroborate suitability of multivariate statistical techniques in the elucidation of various parameters for water quality monitoring and determination of different contamination sources.
\end{abstract}

Keywords High altitude $\cdot$ Indus River $\cdot$ Multivariate statistical analysis $\cdot$ Water quality

Vijay K. Bharti

vijaykbharti@ rediffmail.com

Arup Giri

arupsatadal@gmail.com

Sahil Kalia

sahilkalia87@gmail.com

Krishna Kumar

drkrishna02@gmail.com

Tilak Raj

tilakrajkundan@gmail.com

O. P. Chaurasia

opchaurasia1998@gmail.com

1 Defence Institute of High Altitude Research (DIHAR), Defence Research and Development Organization (DRDO), Ministry of Defence, C/o- 56 APO, Leh 194101, India

\section{Introduction}

The Indus River and their tributaries are one of Asia's largest river systems. It originates from Tibet (northwestern foothill of the Himalayas). It is $3500 \mathrm{~km}$ long, out of which $1500 \mathrm{~km}$ flows through the Indian state of Jammu and Kashmir, and finally joins the Arabian Sea. It flows in between the Ladakh range and the Zanskar range, a high-altitude region of India. This river system is the lifeline for the civil populace for drinking water, agriculture purposes, etc., and therefore assessment of their water quality is gaining pace in recent time (State of Environment Report 2013). The seasonal and annual river flows are highly variable (Ahmad and Qadi 2011; Asianics Agro-Dev. International 2000). Annual peak flow occurs between June and late September, during the southwest monsoon. The high flows of the summer monsoon 
are augmented by snowmelt in the north that also transports a large volume of sediment from the mountains.

In this study area, local populations are thoroughly dependent on Indus River for drinking water, domestic usage, and irrigation purposes. Therefore, there are multiple factors affecting their water quality, and evaluating important factors is necessary to monitor their portability as per public health concern. Some of the earlier studies were conducted to analyze the river water quality (Charan 2013; Bharti et al. 2017). In these studies, it was indicated that the river water quality was deteriorating, but the possible factors were not determined. Studies conducted earlier have indicated that river water chemistry is characterized by the complex correlation among a range of the physicochemical and biological variables in water. Therefore, the present study was undertaken to identify important factors among large data set significantly affecting the quality of river water. Application of multivariate statistical techniques reveals such relationships using analytical techniques such as the principal component analysis (PCA), factor analysis (FA), and cluster analysis (CA). The execution of the multivariate statistical analysis with a large amount of data provides a reliable alternative approach for understanding and interpreting the complex system of water quality.

\section{Materials and methods}

\section{Ethics statement}

It has no requirements for any specific permits to conduct a field study as it is not related to any endangered or protected species.

\section{Materials}

Analytical grade chemicals (Merck, India) were used to analyze various parameters of the Indus River water. All glassware and other sample containers were rinsed with double-distilled water and sterilized prior to use.

\section{Study area}

Leh is the main district of the Ladakh region situated between $32^{\circ}-36^{\circ}$ north latitude and $75^{\circ}-80^{\circ}$ east longitude, at a height of $2300-5000 \mathrm{~m}$ above msl. From the climatic point of view, this region is characterized by both arctic and desert climates. Therefore, Ladakh is often called "COLD DESERT."

In this region, the rocks are igneous, metamorphic, and sedimentary in nature. Lithologically, the soils of the study area are mainly of the sandy type, followed by silt and clay. Analysis of soil characteristics was carried out with a soil hydrometer (Model No 2151H Soil Hydrometer) according to the method described by Singh et al. (2005). The analyzed data showed that sand, silt, and clay constituted $80.73 \%$, $12.83 \%$, and $6.44 \%$ of the soil, respectively.

\section{Sample collection}

Twenty-eight water samples each of both the seasons (summer and winter) were collected from the Indus River between 10.00 and $12.00 \mathrm{~h}$. All the sampling sites were located near the village and farmland. The water samples were collected at a depth of $10 \mathrm{~cm}$ and placed into 500-mL polypropylene bottles (Tarson Company). Samples were stored in the laboratory at the temperature of $0-4{ }^{\circ} \mathrm{C}$ for subsequent chemical analysis (Water Quality-Sampling-Part 11, 1992). The chemical measurements were taken in the laboratory within $24 \mathrm{~h}$ after the collection of the water samples. GPS readings were taken to identify the sampling locations with the help of Garmin GPS 72H. QGIS Desktop 3.0 (Fig. 1).

\section{Sample treatment and sample analysis}

Samples were collected in two bottles. The sampling bottles were washed, rinsed with distilled water, and dried before use. For physicochemical analysis, water samples were preserved with toluene.

In situ parameters, such as temperature (TEMP), $\mathrm{pH}$, electrical conductivity (EC), salinity, total dissolved solid (TDS), and dissolved oxygen (DO), were analyzed by using Hach SensION 156 (APHA 1998). Turbidity (TUR) was measured by using Hach portable turbidity meter (2100Q01) (APHA 1998). These parameters were recorded on the spot during the sample collection. Major anions such as carbonate $\left(\mathrm{CO}_{3}\right)$ and bicarbonate $\left(\mathrm{HCO}_{3}{ }^{-}\right)$were immediately analyzed with the titrimetric method (Singh et al. 2005). Hardness was measured with the titrimetric method (APHA 2012). The level of chloride $\left(\mathrm{Cl}^{-}\right)$was detected by using Mohr's method (APHA 2012). Other anions, such as sulfate $\left(\mathrm{SO}_{4}{ }^{2-}\right)$, nitrate $\left(\mathrm{NO}_{3}{ }^{-}\right)$, and orthophosphate $\left(\mathrm{PO}_{4}{ }^{3-}\right)$, were analyzed through the protocol as described by American Public Health Association (APHA 2012). All the parameters, units, analytical method, instruments, and references are listed in Table 1.

E. coli in water samples were identified with the pour plate method as described in the Medical Laboratory Manual for Tropical Country. Water samples were aliquoted into sterile MacConkey agar plates and uniformly spread over the entire surface of the agar and incubated at $44{ }^{\circ} \mathrm{C}$ for $48 \mathrm{~h}$. The total number of colonies of E. coli was counted, and the mean value of three replicates was calculated (MacConkey 1905).

For mineral analysis, water samples were digested on a mass-to-weight basis, using metal grade $69 \%$ nitric acid 


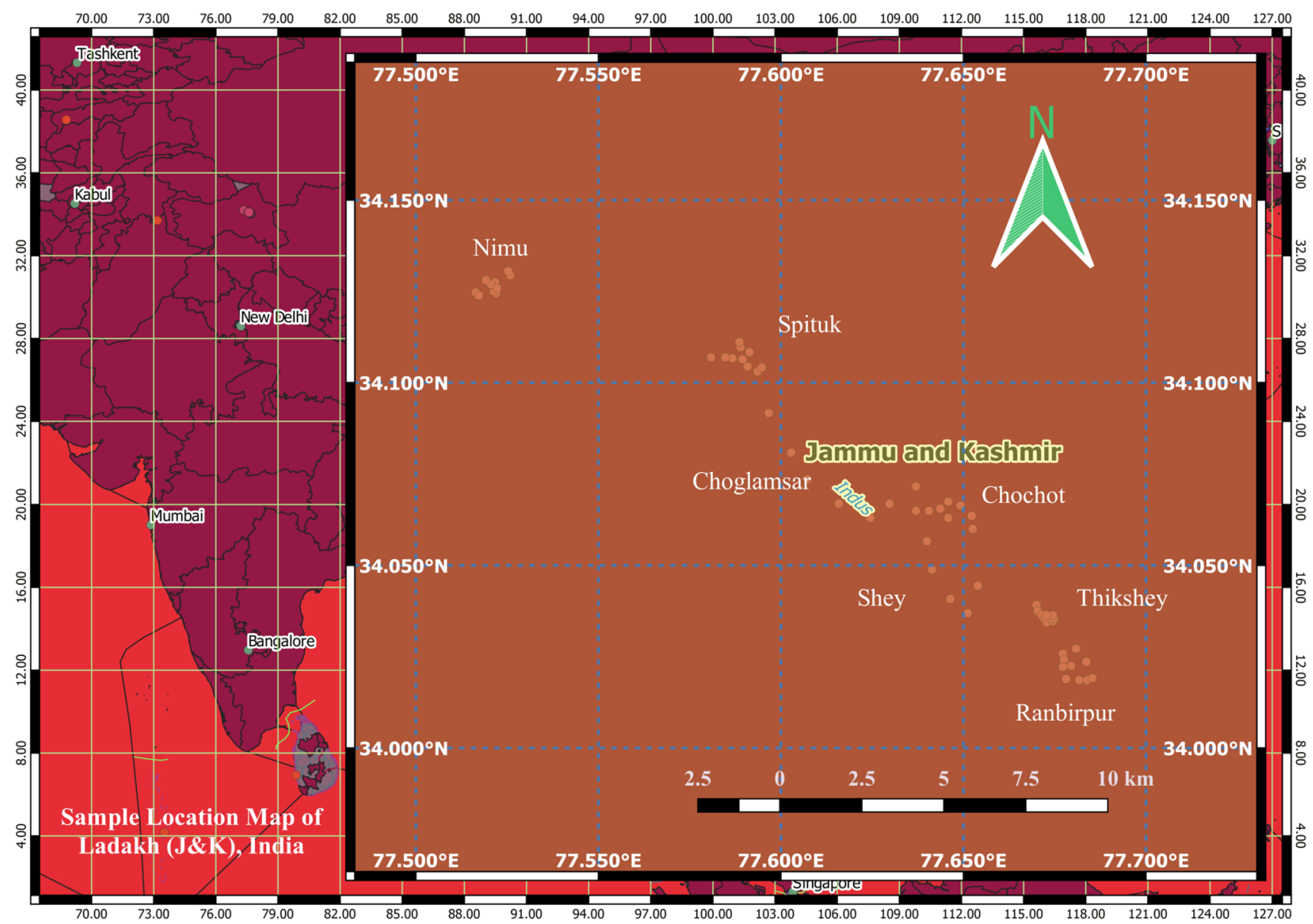

Fig. 1 Sample collection sites made by QGIS software

$\left(\mathrm{HNO}_{3}\right), 60 \%$ perchloric acid $\left(\mathrm{HClO}_{4}\right)$, and $35.40 \%$ hydrochloric acid (HCl). Samples were digested on 42 blocks of an Automated Hot Bock digestion system (Questron Technologies Inc., Canada). All the minerals were estimated in the digested water samples by inductively coupled plasma optical emission spectroscopy (ICP-OES) (Perkin-Elmer Analyst, Optima 7000 DV) (Charan et al. 2013). During the sample analysis by ICP-OES, plasma conditions were as follows: plasma flow $15 \mathrm{Lt} / \mathrm{min}$, auxiliary gas flow $0.2 \mathrm{Lt} / \mathrm{min}$, nebulizer gas flow $0.8 \mathrm{Lt} / \mathrm{min}$, RF power $1300 \mathrm{~W}$, and pump flow rate $1.5 \mathrm{~mL} / \mathrm{min}$.

\section{Data treatment and statistical analysis}

All the mathematical and statistical computations were made using Microsoft Office Excel 2007, Statistical Package for Social Sciences (SPSS) version 22, and Minitab 17 statistical packages. The data were standardized by using standard statistical procedures. The data were subjected to PCA to reduce the dimensionality of the data by explaining the correlations among a large number of variables in terms of a smaller number of underlying factors (principal components or PCs) and then applying R\&Q mode varimax rotation for finding more clearly defined factors called varifactors or VFs after running the FA that facilitates interpretation of the data (Helena et al. 2000; Reghunath et al. 2002). Finally, Q-mode CA was carried out to identify the similarity among all the samples (Reghunath et al. 2002).

\section{Statistical procedures}

In PCA, eigenanalysis of the experimental data was performed to extract principal components (PCs) using two selection criteria: the scree plot test and corrected average eigenvalue. For hierarchical CA, the squared Euclidean distance between normalized data was used to measure the similarity between samples. Both average linkages between groups and Ward's method were applied to standardized data, and the results obtained were represented in a dendrogram. All the mathematical and statistical computations were made using Microsoft Office Excel 2007, Statistical Package for Social Sciences (SPSS) version 22, and Minitab 17 statistical packages. 
Table 1 Physicochemical parameters determined and analytical techniques used

\begin{tabular}{|c|c|c|c|c|c|}
\hline Sl. no. & Parameter & Abbreviation & Unit & Method/equipment used & References \\
\hline 01 & Temperature & TEMP & ${ }^{\circ} \mathrm{C}$ & Hach instrumental method & APHA (1998) \\
\hline 02 & $\mathrm{pH}$ & $\mathrm{pH}$ & - & $\begin{array}{l}\text { HACH ion-selective instrumental } \\
\text { method }\end{array}$ & APHA (1998) \\
\hline 03 & Electrical conductivity & $\mathrm{EC}$ & $\mu \mathrm{S} / \mathrm{cm}$ & $\begin{array}{l}\text { HACH ion-selective instrumental } \\
\text { method }\end{array}$ & APHA (1998) \\
\hline 04 & Total dissolved solids & TDS & $\mathrm{mg} / \mathrm{L}$ & $\begin{array}{l}\text { HACH ion-selective instrumental } \\
\text { method }\end{array}$ & APHA (1998) \\
\hline 05 & Salinity & SAL & ppt & $\begin{array}{l}\text { HACH ion-selective instrumental } \\
\text { method }\end{array}$ & APHA (1998) \\
\hline 06 & Turbidity & TUR & NTU & $\begin{array}{l}\text { Nephelometric method by turbidity } \\
\text { meter }\end{array}$ & APHA (1998) \\
\hline 07 & Total hardness & $\mathrm{TH}$ & $\mathrm{mg} / \mathrm{L}$ & EDTA titrimetric method & APHA (2012) \\
\hline 08 & Chloride & $\mathrm{Cl}$ & $\mathrm{mg} / \mathrm{L}$ & Mohr's method & APHA (2012) \\
\hline 09 & Dissolved oxygen & DO & $\mathrm{mg} / \mathrm{L}$ & $\begin{array}{l}\text { HACH ion-selective instrumental } \\
\text { method }\end{array}$ & Manivaskam (1997) \\
\hline 10 & Carbonate and bicarbonate & $\mathrm{CO}_{3}, \mathrm{HCO}_{3}$ & $\mathrm{mg} / \mathrm{L}$ & Titrimetric method & Singh et al. 2005 \\
\hline 11 & Alkalinity & ALK & $\mathrm{mg} / \mathrm{L}$ & Titrimetric method & APHA (2012) \\
\hline 12 & Sulfate & $\mathrm{SO}_{4}$ & $\mathrm{mg} / \mathrm{L}$ & UV visible spectrophotometric method & APHA (2012) \\
\hline 13 & Nitrate & $\mathrm{NO}_{3}$ & $\mathrm{mg} / \mathrm{L}$ & UV visible spectrophotometric method & APHA (2012) \\
\hline 14 & Phosphate & $\mathrm{PO}_{4}$ & $\mathrm{mg} / \mathrm{L}$ & UV visible spectrophotometric method & APHA (2012) \\
\hline 15 & $\begin{array}{l}\text { Minerals (sodium, potassium, calcium, } \\
\text { magnesium, manganese, phosphorus, } \\
\text { iron, zinc, copper, silica) }\end{array}$ & $\begin{array}{l}\mathrm{Na}, \mathrm{K}, \mathrm{Ca}, \mathrm{Mg}, \\
\mathrm{Mn}, \mathrm{P}, \mathrm{Fe}, \mathrm{Zn}, \\
\mathrm{Cu}, \mathrm{Si}\end{array}$ & $\mathrm{mg} / \mathrm{L}$ & ICP-OES instrumental method & Charan (2013) \\
\hline 16 & E. coli & E. coli & $\mathrm{CFU} / \mathrm{mL}$ & Plate count method & MacConkey (1905) \\
\hline
\end{tabular}

\section{Data standardization}

Kaiser-Meyer-Olkin (KMO) and Bartlett's tests were used to determine the data suitability to execute the PCA (Child 2006). KMO is a measure of sample adequacy. If only KMO value is greater than 0.5, PCA can be used. Bartlett's test measures the relationship between the variables at a significance level. In our study, the KMO value of the summer season was 0.676 and that of the winter season was 0.655 (Tables 2, 3, respectively).

\section{Results and discussion}

The present study also evaluated the status of various water quality parameters and revealed the seasonal variation. General descriptive statistics of all the parameters of the summer and winter season is shown in Tables 4 and 5, respectively. Table 6 reveals with the seasonal variation of all the parameters, and it was found that TDS, turbidity, chloride, alkalinity, and calcium hardness showed the significantly lower level in the winter season.
Table 2 Kaiser-Meyer-Olkin value (0.676) of summer season data, which is greater than 0.5 , giving the suitability for PCA of the observation

\begin{tabular}{ll}
\hline KMO and Bartlett's test & \\
\hline Kaiser-Meyer-Olkin measure of sampling adequacy & 0.676 \\
Bartlett's test of sphericity & \\
Approx. Chi-square & 1665.71 \\
df & 300 \\
Sig. & 0.000 \\
\hline
\end{tabular}

Table 3 Kaiser-Meyer-Olkin value (0.655) of winter-season data, which is greater than 0.5 , giving the suitability for PCA of the observation

\begin{tabular}{ll}
\hline KMO and Bartlett's test & \\
\hline Kaiser-Meyer-Olkin measure of sampling adequacy & 0.655 \\
Bartlett's test of sphericity & \\
Approx. Chi-square & 1099.38 \\
df & 300 \\
Sig. & 0.000 \\
\hline
\end{tabular}


Table 4 General descriptive statistics of river water physicochemical and minerals of summer season

\begin{tabular}{|c|c|c|c|c|c|c|}
\hline Sl. no. & Parameters & Unit & Mean \pm SEM & Range & Skewness \pm SEM & Kurtosis \pm SEM \\
\hline 1 & Temperature & ${ }^{\circ} \mathrm{C}$ & $15.66 \pm 0.03$ & $12.20-19.70$ & $1.17 \pm 0.31$ & $0.12 \pm 0.61$ \\
\hline 2 & $\mathrm{pH}$ & - & $8.36 \pm 0.01$ & $8.15-8.53$ & $-0.24 \pm 0.31$ & $1.47 \pm 0.61$ \\
\hline 3 & Conductivity & $\mu \mathrm{S} / \mathrm{cm}$ & $336.43 \pm 3.64$ & $303.00-476.00$ & $3.50 \pm 0.31$ & $14.96 \pm 0.61$ \\
\hline 4 & TDS & $\mathrm{mg} / \mathrm{L}$ & $155.41 \pm 1.09$ & $145.90-176.20$ & $1.40 \pm 0.31$ & $0.72 \pm 0.61$ \\
\hline 5 & Salinity & $\mathrm{ppt}$ & $0.11 \pm 0.00$ & $0.10-0.20$ & $3.56 \pm 0.31$ & $11.07 \pm 0.61$ \\
\hline 6 & Turbidity & NTU & $4.97 \pm 0.29$ & $0.60-11.22$ & $1.03 \pm 0.31$ & $0.57 \pm 0.61$ \\
\hline 7 & Dissolved oxygen & $\mathrm{mg} / \mathrm{L}$ & $10.17 \pm 0.09$ & $7.15-11.71$ & $-1.21 \pm 0.31$ & $6.54 \pm 0.61$ \\
\hline 8 & E. coli & $\mathrm{CFU} / \mathrm{mL}$ & $8.18 \pm 2.43$ & $2.00-98.00$ & $1.17 \pm 0.31$ & $2.26 \pm 0.61$ \\
\hline 9 & Chloride & $\mathrm{mg} / \mathrm{L}$ & $23.48 \pm 0.45$ & $12.81-27.63$ & $-1.42 \pm 0.31$ & $1.42 \pm 0.61$ \\
\hline 10 & Alkalinity & $\mathrm{mg} / \mathrm{L}$ & $333.43 \pm 11.52$ & $226.00-406.00$ & $0.02 \pm 0.31$ & $-0.42 \pm 0.61$ \\
\hline 11 & Calcium hardness & $\mathrm{mg} / \mathrm{L}$ & $88.33 \pm 2.66$ & $25.00-116.00$ & $-1.31 \pm 0.31$ & $1.50 \pm 0.61$ \\
\hline 12 & Total hardness & $\mathrm{mg} / \mathrm{L}$ & $187.27 \pm 5.65$ & $53.00-245.92$ & $-1.31 \pm 0.31$ & $1.50 \pm 0.61$ \\
\hline 13 & Sulfate & $\mathrm{mg} / \mathrm{L}$ & $3.92 \pm 0.10$ & $0.36-4.84$ & $0.63 \pm 0.31$ & $1.78 \pm 0.61$ \\
\hline 14 & Phosphate & $\mathrm{mg} / \mathrm{L}$ & $0.35 \pm 0.06$ & $0.09-1.94$ & $2.05 \pm 0.31$ & $3.11 \pm 0.61$ \\
\hline 15 & Carbonate & $\mathrm{mg} / \mathrm{L}$ & $2.99 \pm 0.20$ & $0.00-6.88$ & $0.29 \pm 0.31$ & $-0.72 \pm 0.61$ \\
\hline 16 & Bicarbonate & $\mathrm{mg} / \mathrm{L}$ & $23.46 \pm 0.48$ & $14.04-30.60$ & $-0.30 \pm 0.31$ & $-0.08 \pm 0.61$ \\
\hline 17 & Fluoride & $\mathrm{mg} / \mathrm{L}$ & $0.30 \pm 0.01$ & $0.12-0.57$ & $0.83 \pm 0.31$ & $0.87 \pm 0.61$ \\
\hline 18 & Nitrate & $\mathrm{mg} / \mathrm{L}$ & $0.12 \pm 0.00$ & $0.10-0.17$ & $0.75 \pm 0.31$ & $-0.29 \pm 0.61$ \\
\hline 19 & TOC & $\mathrm{mg} / \mathrm{L}$ & $1.07 \pm 0.16$ & $0.40-7.30$ & $3.75 \pm 0.31$ & $14.92 \pm 0.61$ \\
\hline 20 & Calcium & $\mathrm{mg} / \mathrm{L}$ & $70.28 \pm 2.28$ & $61.68-73.81$ & $0.26 \pm 0.85$ & $-1.77 \pm 1.74$ \\
\hline 21 & Magnesium & $\mathrm{mg} / \mathrm{L}$ & $31.18 \pm 0.81$ & $29.28-33.86$ & $0.40 \pm 0.85$ & $-2.22 \pm 1.74$ \\
\hline 22 & Iron & $\mathrm{mg} / \mathrm{L}$ & $1.06 \pm 0.02$ & $1.02-1.13$ & $1.00 \pm 0.85$ & $-1.46 \pm 1.74$ \\
\hline 23 & Sodium & $\mathrm{mg} / \mathrm{L}$ & $60.98 \pm 0.47$ & $60.19-62.53$ & $0.97 \pm 0.85$ & $-1.85 \pm 1.74$ \\
\hline 24 & Potassium & $\mathrm{mg} / \mathrm{L}$ & $30.60 \pm 0.23$ & $30.20-31.42$ & $0.99 \pm 0.85$ & $-1.59 \pm 1.74$ \\
\hline 25 & Manganese & $\mathrm{mg} / \mathrm{L}$ & $1.23 \pm 0.16$ & $0.87-1.67$ & $0.07 \pm 0.85$ & $-3.09 \pm 1.74$ \\
\hline
\end{tabular}

All the 25 variables were run through the PCA, which extracted 7 and 8 variables based on the eigenvalues $(>1)$ in summer and winter seasons, respectively. The extracted and non-extracted variables of both seasons are listed in Tables 7 and 8, respectively. Scree plot is shown in Fig. 2.

$\mathrm{R}$-mode factor analysis of all the parameters/variables of water samples was carried out for both seasons and is given in Tables 9 and 10. The analysis of the summer season data matrix generated seven factors that together account for $77.05 \%$ of the variance, whereas the analysis of the winter-season data matrix generated eight factors that account for $76.90 \%$ of the variance. The rotated loadings, eigenvalues, percentage of variance, and cumulative percentage of variance of all the factors of summer and winter seasons are given in Tables 7 and 8, respectively.

The first eigenvalue of the summer season factor analysis is 6.14 , which accounts for $24.56 \%$ of the total variance, and these constitutes the first and main factor. The second and third varifactors have the eigenvalues of 5.24 and 2.84, respectively, which account for $20.95 \%$ and $11.36 \%$ of the 
Table 5 General descriptive statistics of river water physicochemical and minerals of winter season

\begin{tabular}{|c|c|c|c|c|c|c|}
\hline Sl. no. & Parameters & Unit & Mean \pm SEM & Range & Skewness \pm SEM & Kurtosis \pm SEM \\
\hline 1 & Temperature & ${ }^{\circ} \mathrm{C}$ & $14.88 \pm 0.30$ & $15.20-16.40$ & $0.27 \pm 0.31$ & $0.73 \pm 0.61$ \\
\hline 2 & $\mathrm{pH}$ & - & $8.33 \pm 0.02$ & $7.56-8.72$ & $-1.13 \pm 0.31$ & $3.71 \pm 0.61$ \\
\hline 3 & Conductivity & $\mu \mathrm{S} / \mathrm{cm}$ & $326.65 \pm 6.16$ & $0.23-130.00$ & $1.20 \pm 0.31$ & $-0.34 \pm 0.61$ \\
\hline 4 & TDS & $\mathrm{mg} / \mathrm{L}$ & $103.46 \pm 6.94$ & $0.24-156.00$ & $-1.20 \pm 0.31$ & $-0.18 \pm 0.61$ \\
\hline 5 & Salinity & ppt & $0.10 \pm 0.01$ & $0.00-0.30$ & $0.48 \pm 0.31$ & $0.32 \pm 0.61$ \\
\hline 6 & Turbidity & NTU & $3.38 \pm 0.17$ & $0.87-7.22$ & $0.75 \pm 0.31$ & $1.52 \pm 0.61$ \\
\hline 7 & Dissolved oxygen & $\mathrm{mg} / \mathrm{L}$ & $10.69 \pm 0.05$ & $10.00-11.46$ & $0.37 \pm 0.31$ & $-0.80 \pm 0.61$ \\
\hline 8 & E. coli & $\mathrm{CFU} / \mathrm{mL}$ & $6.48 \pm 2.45$ & $0.00-77.00$ & $0.06 \pm 0.31$ & $-0.72 \pm 0.61$ \\
\hline 9 & Chloride & $\mathrm{mg} / \mathrm{L}$ & $20.44 \pm 0.73$ & $10.32-28.23$ & $-0.68 \pm 0.31$ & $-1.23 \pm 0.61$ \\
\hline 10 & Alkalinity & $\mathrm{mg} / \mathrm{L}$ & $319.25 \pm 5.49$ & $108.00-524.00$ & $-0.38 \pm 0.31$ & $0.20 \pm 0.61$ \\
\hline 11 & Calcium hardness & $\mathrm{mg} / \mathrm{L}$ & $53.85 \pm 1.64$ & $19.00-77.00$ & $-0.33 \pm 0.31$ & $0.27 \pm 0.61$ \\
\hline 12 & Total hardness & $\mathrm{mg} / \mathrm{L}$ & $150.67 \pm 4.92$ & $51.56-206.92$ & $-0.93 \pm 0.31$ & $0.45 \pm 0.61$ \\
\hline 13 & Sulfate & $\mathrm{mg} / \mathrm{L}$ & $2.28 \pm 0.10$ & $2.00-6.48$ & $0.63 \pm 0.31$ & $1.78 \pm 0.61$ \\
\hline 14 & Phosphate & $\mathrm{mg} / \mathrm{L}$ & $0.27 \pm 0.06$ & $0.01-1.86$ & $2.05 \pm 0.31$ & $3.11 \pm 0.61$ \\
\hline 15 & Carbonate & $\mathrm{mg} / \mathrm{L}$ & $2.55 \pm 0.20$ & $0.19-6.43$ & $0.36 \pm 0.31$ & $-0.78 \pm 0.61$ \\
\hline 16 & Bicarbonate & $\mathrm{mg} / \mathrm{L}$ & $21.26 \pm 0.48$ & $11.84-28.40$ & $-0.30 \pm 0.31$ & $-0.08 \pm 0.61$ \\
\hline 17 & Fluoride & $\mathrm{mg} / \mathrm{L}$ & $0.20 \pm 0.01$ & $0.02-0.47$ & $0.83 \pm 0.31$ & $0.87 \pm 0.61$ \\
\hline 18 & Nitrate & $\mathrm{mg} / \mathrm{L}$ & $0.04 \pm 0.00$ & $0.02-0.09$ & $0.75 \pm 0.31$ & $-0.29 \pm 0.61$ \\
\hline 19 & TOC & $\mathrm{mg} / \mathrm{L}$ & $0.92 \pm 0.16$ & $0.25-7.15$ & $3.75 \pm 0.31$ & $14.92 \pm 0.61$ \\
\hline 20 & Calcium & $\mathrm{mg} / \mathrm{L}$ & $66.99 \pm 1.99$ & $63.76-84.62$ & $1.26 \pm 0.64$ & $-0.31 \pm 1.23$ \\
\hline 21 & Magnesium & $\mathrm{mg} / \mathrm{L}$ & $31.49 \pm 0.46$ & $29.69-35.90$ & $2.07 \pm 0.64$ & $5.59 \pm 1.23$ \\
\hline 22 & Iron & $\mathrm{mg} / \mathrm{L}$ & $1.07 \pm 0.01$ & $1.04-1.13$ & $0.91 \pm 0.64$ & $-0.26 \pm 1.23$ \\
\hline 23 & Sodium & $\mathrm{mg} / \mathrm{L}$ & $62.16 \pm 0.35$ & $60.56-64.66$ & $0.75 \pm 0.64$ & $-0.01 \pm 1.23$ \\
\hline 24 & Potassium & $\mathrm{mg} / \mathrm{L}$ & $31.63 \pm 0.23$ & $30.54-33.18$ & $0.58 \pm 0.64$ & $-0.52 \pm 1.23$ \\
\hline 25 & Manganese & $\mathrm{mg} / \mathrm{L}$ & $0.62 \pm 0.06$ & $0.34-1.00$ & $0.44 \pm 0.64$ & $-0.62 \pm 1.23$ \\
\hline
\end{tabular}

total variance, respectively. The remaining four eigenvalues each constitute less than $10 \%$ of the total variance. However, in the case of winter-season factor analysis, the first and second varifactors contain the eigenvalues of 4.68 and 3.43 , respectively, which account for $18.72 \%$ and $13.71 \%$ of the total variance, respectively. Except for the third varifactor $(10.86 \%)$, eigenvalues of the remaining five varifactor reveal less than $10 \%$ of the total variance (Table 9).

In the present result of summer factor analysis, the first factor (which accounts for $24.56 \%$ of the total variance) is characterized by higher loadings of calcium (Ca), magnesium $(\mathrm{Mg})$, iron $(\mathrm{Fe}), \operatorname{sodium}(\mathrm{Na}), \operatorname{potassium}(\mathrm{K})$, and manganese (Mn) with moderate loadings of phosphate. This may be due to the influence of non-point sources, such as agricultural runoff or atmospheric deposition by natural weathering (Huang et al. 2013; Boutron et al. 1991; Bohlke et al. 2007). In the study area, chemical fertilizers are used by farmers in the summer season (Mann 2002; Acharya et al. 2012). For this reason, the phosphate loading is probably a moderate-type loading. The agricultural runoff or weathering process enhances the ion exchange and oxidation-reduction conditions. These cumulatively induce the 
Table 6 Result after the execution of $\mathrm{T}$ test on the parameters of river water

\begin{tabular}{|c|c|c|c|c|}
\hline Sl. no. & Parameters & Unit & $\begin{array}{l}\text { Summer } \\
\text { Mean } \pm \text { SEM }\end{array}$ & $\begin{array}{l}\text { Winter } \\
\text { Mean } \pm \text { SEM }\end{array}$ \\
\hline 1 & Temperature & ${ }^{\circ} \mathrm{C}$ & $15.66 \pm 0.03$ & $14.88 \pm 0.30$ \\
\hline 2 & $\mathrm{pH}$ & - & $8.36 \pm 0.01$ & $8.33 \pm 0.02$ \\
\hline 3 & Conductivity & $\mu \mathrm{S} / \mathrm{cm}$ & $336.43 \pm 3.64$ & $326.65 \pm 6.16$ \\
\hline 4 & TDS & $\mathrm{mg} / \mathrm{L}$ & $155.41 \pm 1.09$ & $103.46 \pm 6.94 *$ \\
\hline 5 & Salinity & ppt & $0.11 \pm 0.00$ & $0.10 \pm 0.01$ \\
\hline 6 & Turbidity & NTU & $4.97 \pm 0.29$ & $3.38 \pm 0.17^{*}$ \\
\hline 7 & $\begin{array}{c}\text { Dissolved } \\
\text { oxygen }\end{array}$ & $\mathrm{mg} / \mathrm{L}$ & $10.17 \pm 0.09$ & $10.69 \pm 0.05$ \\
\hline 8 & E. coli & $\mathrm{CFU} / \mathrm{mL}$ & $8.18 \pm 2.43$ & $6.48 \pm 2.45$ \\
\hline 9 & Chloride & $\mathrm{mg} / \mathrm{L}$ & $23.48 \pm 0.45$ & $20.44 \pm 0.73 *$ \\
\hline 10 & Alkalinity & $\mathrm{mg} / \mathrm{L}$ & $333.43 \pm 11.52$ & $319.25 \pm 5.49 *$ \\
\hline 11 & $\begin{array}{l}\text { Calcium hard- } \\
\text { ness }\end{array}$ & $\mathrm{mg} / \mathrm{L}$ & $88.33 \pm 2.66$ & $53.85 \pm 1.64 *$ \\
\hline 12 & Total hardness & $\mathrm{mg} / \mathrm{L}$ & $187.27 \pm 5.65$ & $150.67 \pm 4.92$ \\
\hline 13 & Sulfate & $\mathrm{mg} / \mathrm{L}$ & $3.92 \pm 0.10$ & $2.28 \pm 0.10$ \\
\hline 14 & Phosphate & $\mathrm{mg} / \mathrm{L}$ & $0.35 \pm 0.06$ & $0.27 \pm 0.06$ \\
\hline 15 & Carbonate & $\mathrm{mg} / \mathrm{L}$ & $2.99 \pm 0.20$ & $2.55 \pm 0.20$ \\
\hline 16 & Bicarbonate & $\mathrm{mg} / \mathrm{L}$ & $23.46 \pm 0.48$ & $21.26 \pm 0.48$ \\
\hline 17 & Fluoride & $\mathrm{mg} / \mathrm{L}$ & $0.30 \pm 0.01$ & $0.20 \pm 0.01$ \\
\hline 18 & Nitrate & $\mathrm{mg} / \mathrm{L}$ & $0.12 \pm 0.00$ & $0.04 \pm 0.00$ \\
\hline 19 & TOC & $\mathrm{mg} / \mathrm{L}$ & $1.07 \pm 0.16$ & $0.92 \pm 0.16$ \\
\hline 20 & Calcium & $\mathrm{mg} / \mathrm{L}$ & $70.28 \pm 2.28$ & $66.99 \pm 1.99$ \\
\hline 21 & Magnesium & $\mathrm{mg} / \mathrm{L}$ & $31.18 \pm 0.81$ & $31.49 \pm 0.46$ \\
\hline 22 & Iron & $\mathrm{mg} / \mathrm{L}$ & $1.06 \pm 0.02$ & $1.07 \pm 0.01$ \\
\hline 23 & Sodium & $\mathrm{mg} / \mathrm{L}$ & $60.98 \pm 0.47$ & $62.16 \pm 0.35$ \\
\hline 24 & Potassium & $\mathrm{mg} / \mathrm{L}$ & $30.60 \pm 0.23$ & $31.63 \pm 0.23$ \\
\hline 25 & Manganese & $\mathrm{mg} / \mathrm{L}$ & $1.23 \pm 0.16$ & $0.62 \pm 0.06$ \\
\hline
\end{tabular}

*Level of significance at the 0.05 level

nutrient solubility (Bohlke et al. 2007; Seiler et al. 2003). In this way, our finding of nutrient loading in the study area through agricultural runoff or atmospheric deposition may be possible (Huang et al. 2013).

The second factor (which accounts for $20.95 \%$ of the total variance) is characterized by very high loadings of calcium hardness (CaHard) and total hardness (ToHard), followed by higher loadings of chloride (Chl) and alkalinity (Alk). It is also revealed with the higher negative loading of temperature (Temp) followed by moderate loadings of E. coli. One of our previous studies showed that the total hardness level is high in river water due to the higher levels of calcium and magnesium entering the water, which might be due to the weather factor as higher negative loadings of temperature (Bharti et al. 2017; Nelson 2002; Grift et al. 2016). Higher loadings of $\mathrm{Ca}$ and $\mathrm{Mg}$ were seen in the first factor, and these are strongly related to our previous study (Bharti et al. 2017). High loadings of chloride might be from the dissolution of salts due to the weathering process or oxidation-reduction reaction (Sarin et al. 1989; Datta and Tyagi 1996; Liang et al. 2016). One of the previous studies in this study area on the soil had estimated that the soil alkalinity level is high (Charan 2013). The present study has shown moderate loading of alkalinity in the groundwater (Bharti et al. 2017). Because of a poor sanitation system, moderate loading of E. coli was found in this study area (Anonymous 2009; Affum et al. 2015). Meanwhile, Water Stewardship Information Series (2007) has documented that infiltration of domestic or wild animal fecal matter may act as a source of E. coli. River sites are highly affected by the presence of wild and domestic animals in this area. None of the factors of the winter-season data matrix (Table 10) show any loadings of E. coli. This strongly establishes that the river site is moderately affected by the presence of E. coli in the summer seasons.

Factors 4-7 are characterized by the dominance of only one variable each, such as dissolved oxygen (factor 4), nitrate (factor 5), $\mathrm{pH}$ (factor 6), carbonate (factor 7), whereas factor 3 showed higher loadings of conductivity (COND) and TDS (Table 8). High loadings of TDS and COND are revealed with the physiochemical sources of variability (Varrol and Sen 2009). Negative moderate loading of $\mathrm{pH}$ might indicate the increase in dissolved organic carbon (DOC) from the runoff (Dinka 2010).

The output of the R-mode cluster analysis of the summer season is given as a dendrogram (Fig. 3). The dendrogram 
Table 7 Extracted components based on eigenvalue after PCA of summer season data

\begin{tabular}{|c|c|c|c|c|c|c|}
\hline \multirow[t]{2}{*}{ Component } & \multicolumn{3}{|c|}{ Initial eigenvalues } & \multicolumn{3}{|c|}{ Rotation sums of squared loadings } \\
\hline & Total & $\%$ of variance & Cumulative $\%$ & Total & $\%$ of variance & Cumulative $\%$ \\
\hline \multicolumn{7}{|c|}{ Total variance explained } \\
\hline 1 & 6.63 & 26.51 & 26.51 & 6.14 & 24.56 & 24.56 \\
\hline 2 & 5.24 & 20.97 & 47.48 & 5.24 & 20.95 & 45.51 \\
\hline 3 & 2.72 & 10.88 & 58.36 & 2.84 & 11.36 & 56.86 \\
\hline 4 & 1.38 & 5.54 & 63.89 & 1.37 & 5.50 & 62.36 \\
\hline 5 & 1.17 & 4.67 & 68.57 & 1.37 & 5.50 & 67.86 \\
\hline 6 & 1.11 & 4.44 & 73.00 & 1.20 & 4.81 & 72.68 \\
\hline 7 & 1.01 & 4.05 & 77.05 & 1.09 & 4.38 & 77.05 \\
\hline 8 & 0.97 & 3.86 & 80.92 & & & \\
\hline 9 & 0.75 & 3.00 & 83.91 & & & \\
\hline 10 & 0.66 & 2.64 & 86.55 & & & \\
\hline 11 & 0.61 & 2.43 & 88.99 & & & \\
\hline 12 & 0.53 & 2.12 & 91.11 & & & \\
\hline 13 & 0.46 & 1.85 & 92.96 & & & \\
\hline 14 & 0.42 & 1.70 & 94.65 & & & \\
\hline 15 & 0.38 & 1.54 & 96.19 & & & \\
\hline 16 & 0.35 & 1.38 & 97.58 & & & \\
\hline 17 & 0.20 & 0.82 & 98.39 & & & \\
\hline 18 & 0.17 & 0.67 & 99.07 & & & \\
\hline 19 & 0.10 & 0.40 & 99.47 & & & \\
\hline 20 & 0.05 & 0.22 & 99.69 & & & \\
\hline 21 & 0.04 & 0.15 & 99.84 & & & \\
\hline 22 & 0.02 & 0.09 & 99.94 & & & \\
\hline 23 & 0.01 & 0.05 & 99.98 & & & \\
\hline 24 & 0.00 & 0.01 & 100.00 & & & \\
\hline 25 & 0.00 & 0.00 & 100.00 & & & \\
\hline
\end{tabular}

Extraction method: principal component analysis contains two major clusters as shown in Fig. 3. Clusters 1 and 2 show the interrelationship among the variables. Cluster 1 shows the interrelationship among the minerals that are found in Factor 1 of the R-mode factor analysis. This dendrogram validates the interpretation in the R-mode factor analysis (Reghunath et al. 2002).

Varimax rotation of winter-season data showed eight varifactors. The first factor (which accounts for $18.72 \%$ of the total variance) is characterized with higher loadings of iron, sodium, and potassium, followed by negative higher loadings of TDS, and negative lower loadings of chloride and phosphate (Table 10). It has been found that the number of nutrient loadings was less in comparison with the first varifactor of the summer season. It might be due to less weathering and agricultural runoff. The temperature is very low in the winter season in this area, and no cultivation is found in this season in the study area. For these reasons, the number of nutrient loadings is less $(5,29-31,45)$. Negative moderate loadings of phosphate might be due to the zero level of agriculture in this area. Negative higher loading of TDS might be due to the few physicochemical sources of variability. In the second varifactor, higher loadings of bicarbonate and manganese were found and this might be due to the weathering process of rocks (Kumar et al. 2009). 
ㄱำริก

m

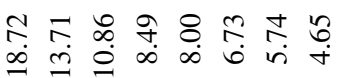

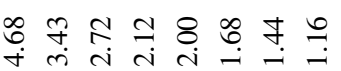

ดे

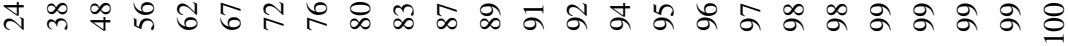

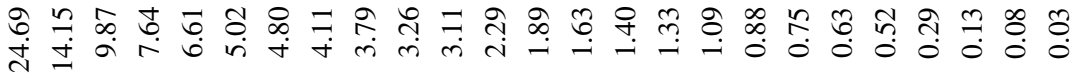

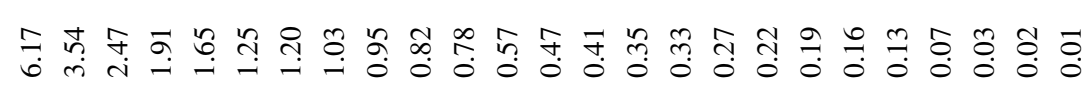

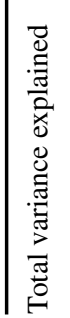




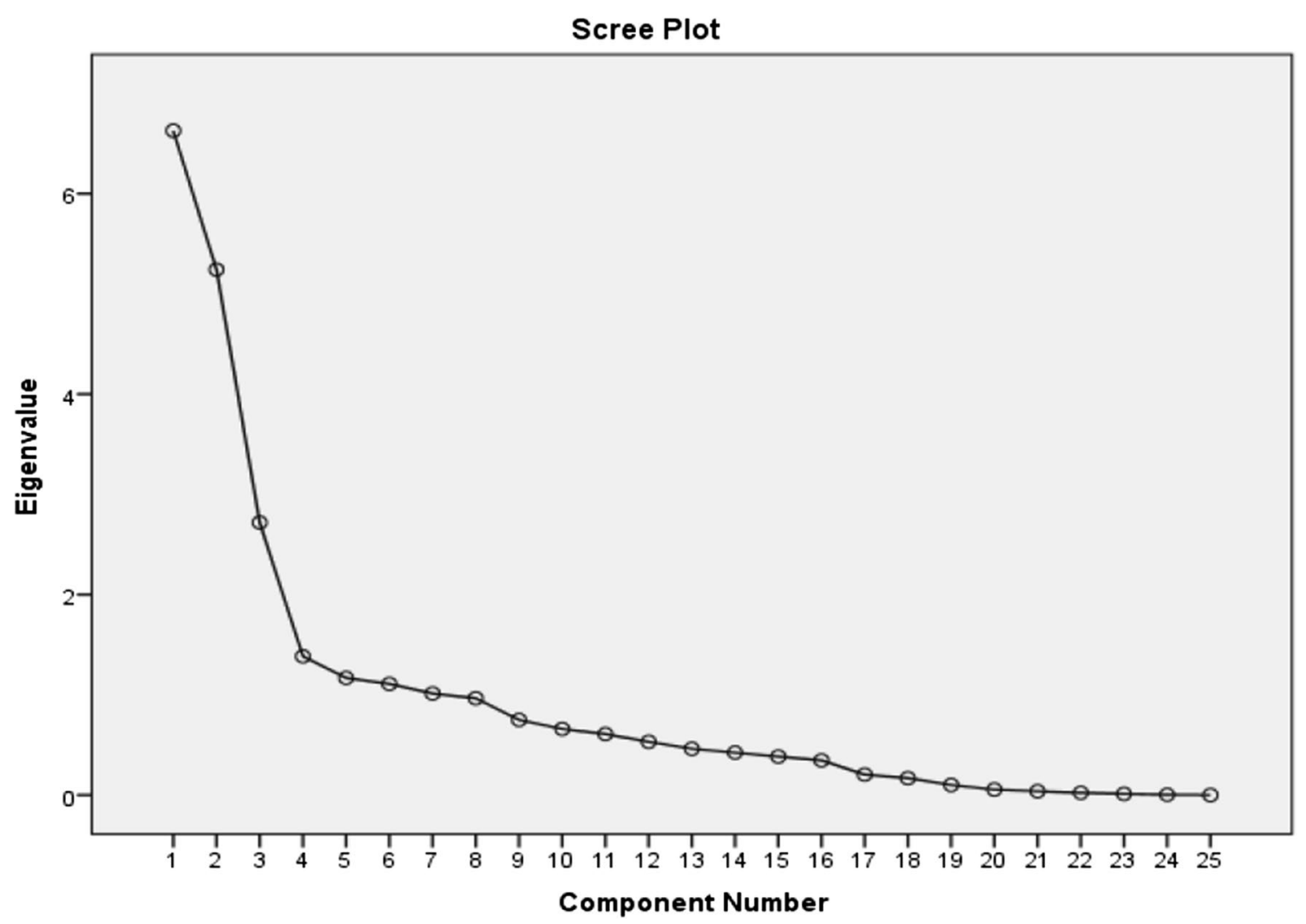

Fig. 2 Scree plot of eigenvalues of physico-chemical variables of surface water of summer water in Leh, Jammu \& Kashmir, India

Factors 3-8 are characterized by the dominance of only one variable each, such as $\mathrm{Ca}$ (factor 3 ), calcium hardness (factor 4), alkalinity (factor 5), dissolved oxygen (factor 6), $\mathrm{pH}$ (factor 7), and salinity (factor 8) (Table 10). All these factors account for $44.47 \%$ of the total variance. The single dominance of variables in each factor indicates non-mixing or partial mixing of different types of water (Arshad and Gopalakrishna 2009). The present results were in accordance with the study of Reghunath et al. (2002). In their study, it was found that factors 3-8 are characterized by the dominance of only one variable each, such as $\mathrm{Mg}$ in factor $3, \mathrm{~K}$ in factor $4, \mathrm{NO}_{3}{ }^{-}$in factor 5 , $\mathrm{CO}_{3}$ in factor $6, \mathrm{pH}$ in factor 7 , and $\mathrm{SO}_{4}{ }^{-}$in factor 8 , and together, these six factors account for $34.7 \%$ of the total variance. The results of this study strongly agreed with those of our study. Therefore, there is a strong indication that non-mixing/partial mixing of different types of water is present in the study area (Tables 9 and 10).

The output of the R-mode cluster analysis of the winter season is given as a dendrogram (Fig. 4). The dendrogram contains two major clusters, as shown in Fig. 4. Clusters 1 and 2 show the interrelationship among the variables. Cluster 1 shows the presence of variable that has the higher loadings in most of the varifactors. This dendrogram confirms the interpretation made in the R-mode factor analysis (Reghunath et al. 2002) (Fig. 4). 
昰

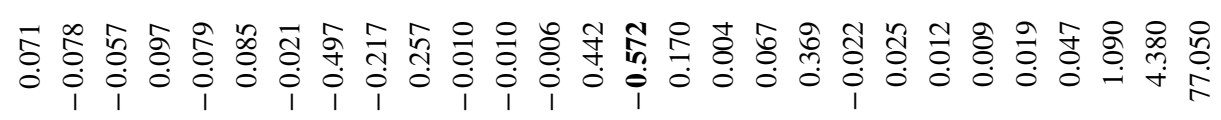

$\stackrel{\circ}{>}$

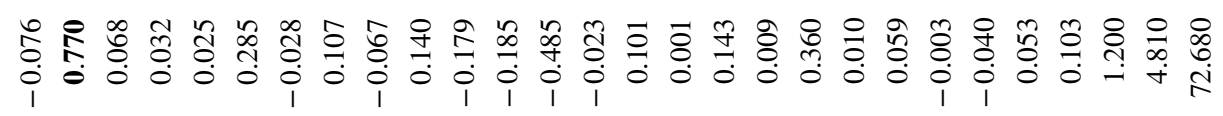

$\stackrel{n}{>}$

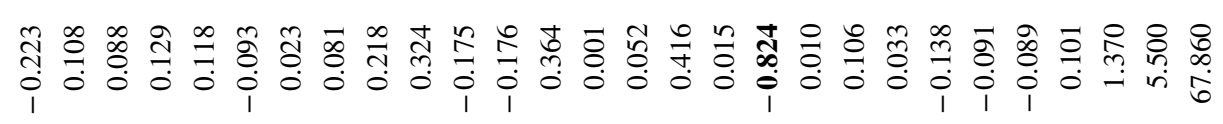

$\stackrel{+1}{>}$

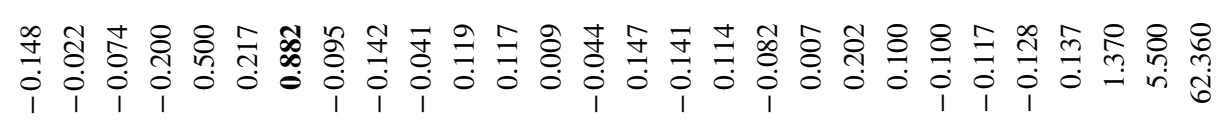

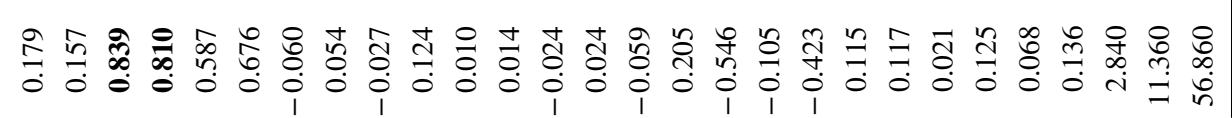

年

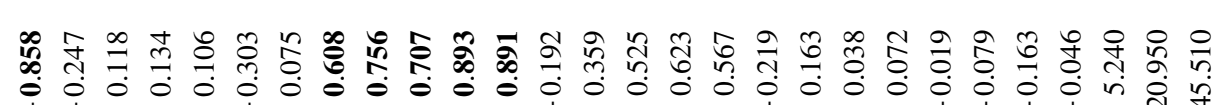

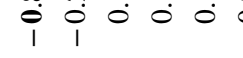
ด.

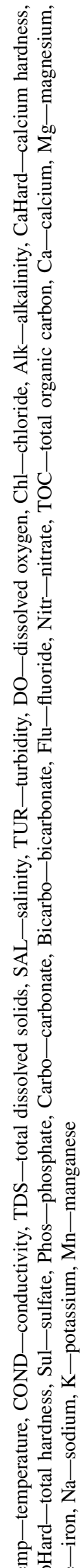

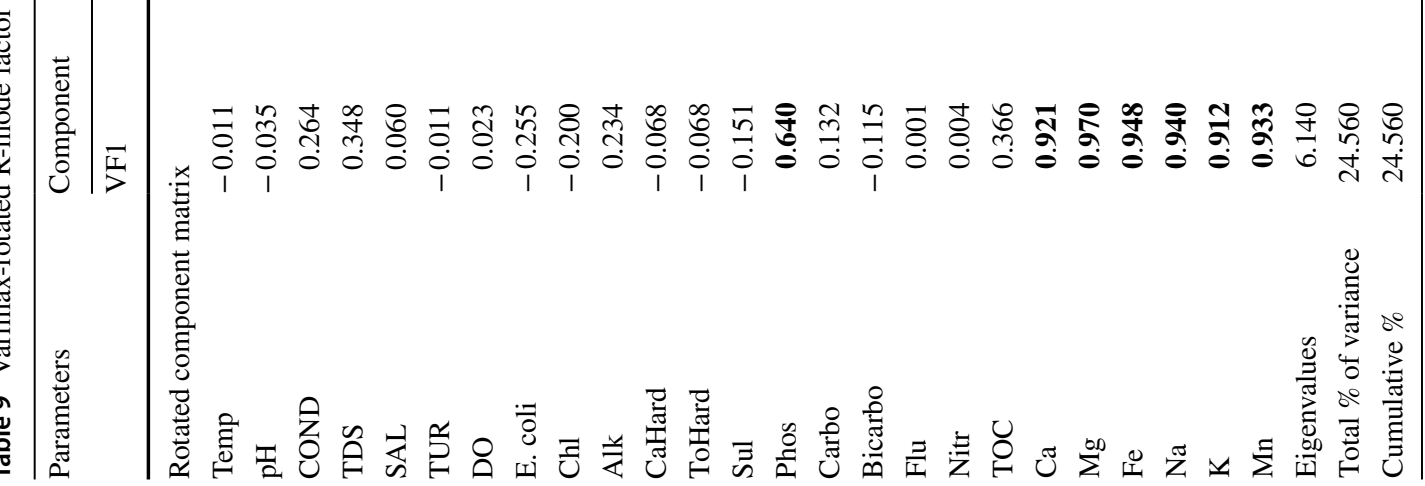


$\stackrel{\infty}{>}$

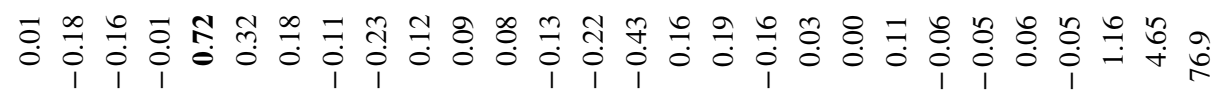

质

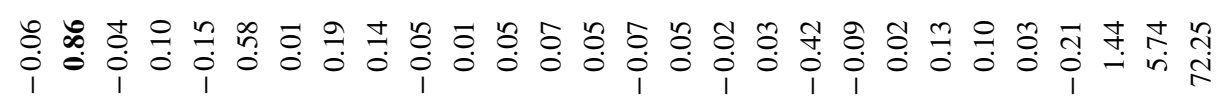

这

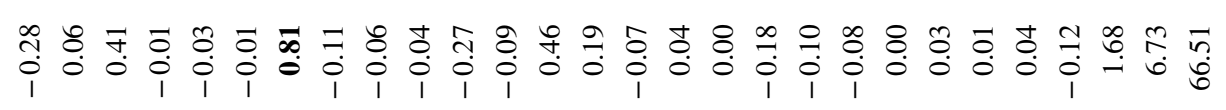

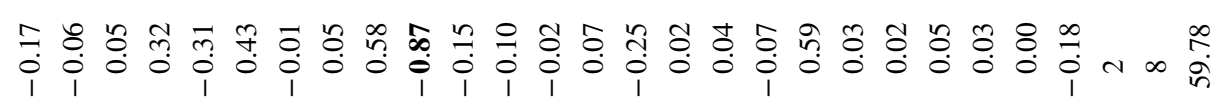

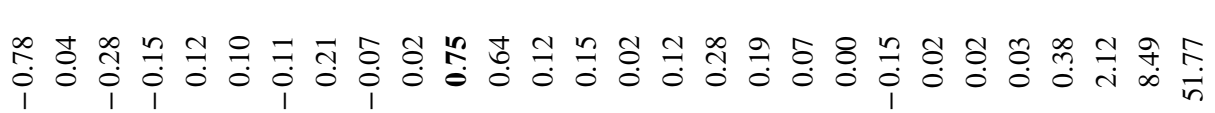

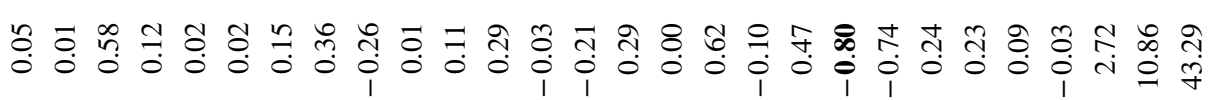

$\stackrel{\sim}{>}$

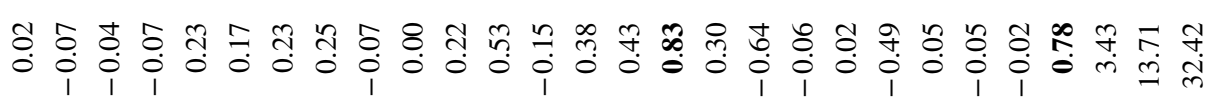

$\times 8$

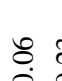

$\stackrel{n}{\infty} \infty$

$\stackrel{\infty}{\infty} \stackrel{\infty}{\infty} \stackrel{\infty}{\infty} \stackrel{\infty}{0}$

$\stackrel{\infty}{\infty}: 0$

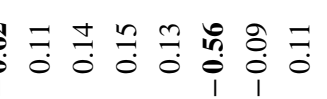

$=$ 궁융

:

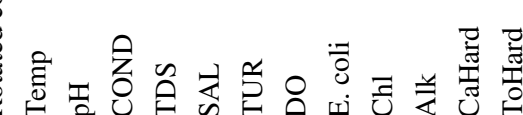

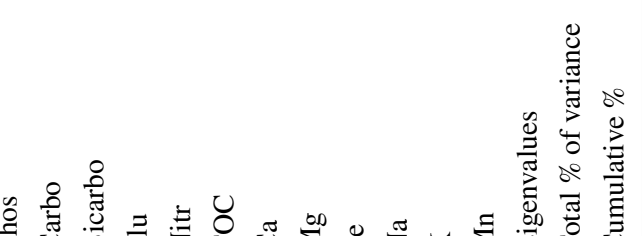


Fig. 3 Scree plot of eigenvalues of physicochemical variables of surface water of summer water in Leh, Jammu and Kashmir, India

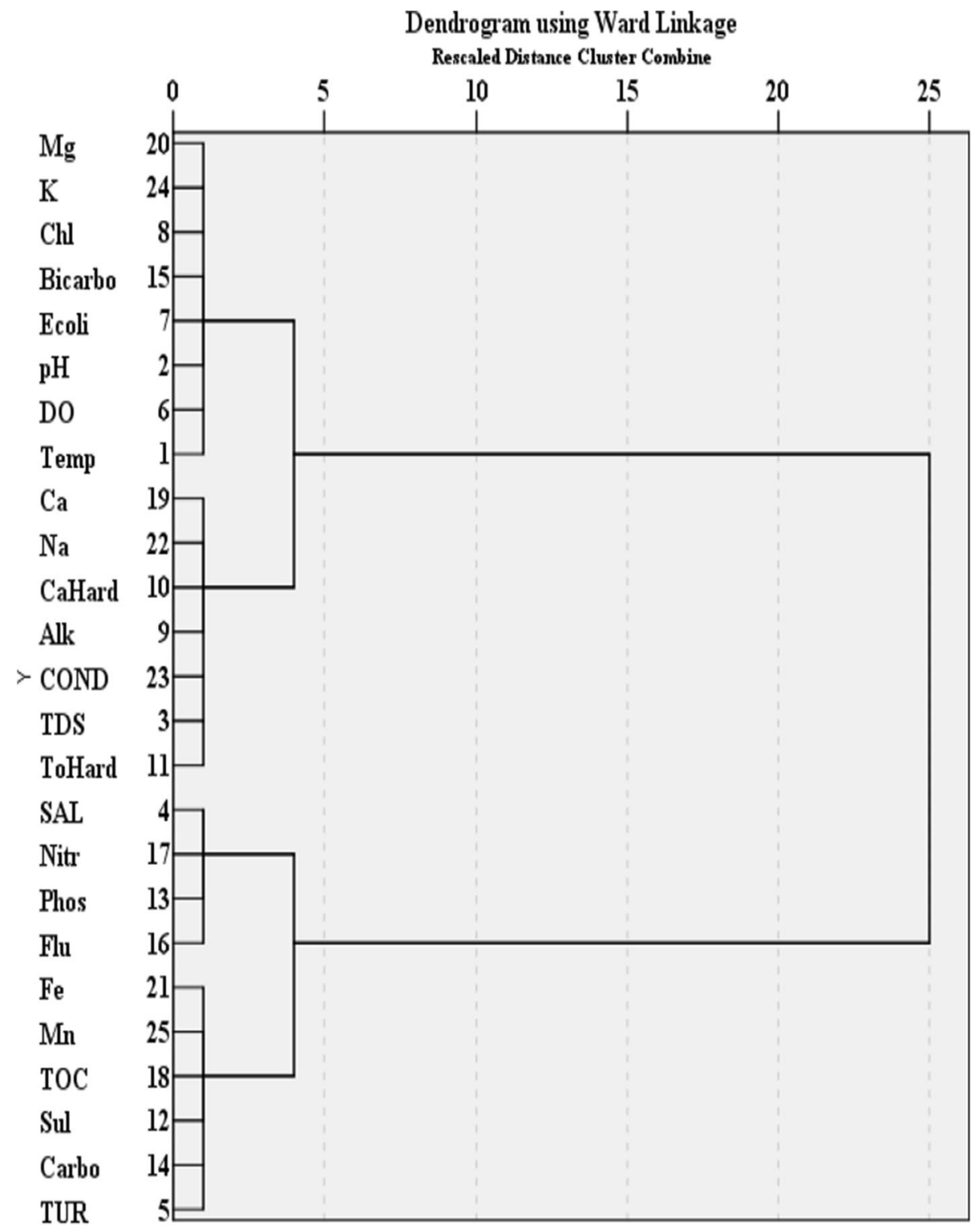

\section{Conclusions}

New information on seasonal variation of different water quality parameters, viz physical, chemical, and microbiological of the Indus River water from the Trans-Himalayan high-altitude region, has been analyzed. As per principal component analysis, followed by factor analysis, the loading results of the seven varifactors in summer season and eight varifactors in winter seasons were extracted. These findings indicated that the anthropogenic activities and nutrient loading are the main factors affecting the river water quality in the summer seasons. However, in the winter seasons, through factor analysis, it might be inferred that the river water in the winter season has been 
Fig. 4 Dendrogram of the Q-mode cluster analysis of winter season. (The axis shown below indicates the relative similarity of different cluster groups. The lesser the distance, the greater the similarity between objects)

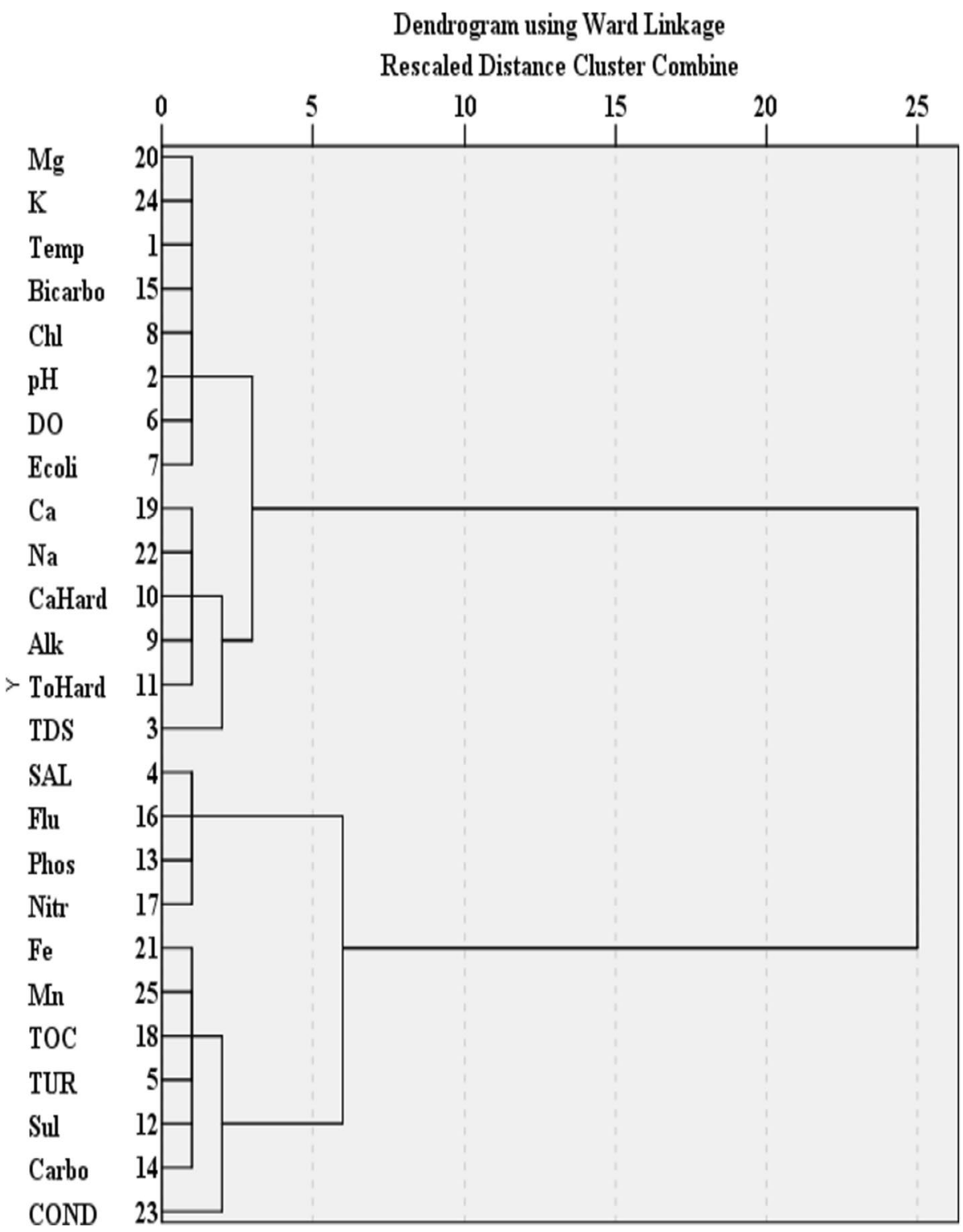

less affected by anthropogenic activities. With reference to multivariate statistical analyses, it can be concluded that the agricultural, domestic, and hydrogeochemical sources are affecting significantly water quality of the Indus River.

Acknowledgements The authors are thankful to Defence Research and Developmental Organization (DRDO), New Delhi, India. We are also thankful to the Head, Animal Science Division, for the support and guidance. A special thanks to Dr. Girish Korekar, Sahil Kapoor, and Avilekh for their technical assistance.

\section{Compliance with ethical standards}

Conflict of interest All authors declare that they have no conflict of interest.
Open Access This article is distributed under the terms of the Creative Commons Attribution 4.0 International License (http://creativeco mmons.org/licenses/by/4.0/), which permits unrestricted use, distribution, and reproduction in any medium, provided you give appropriate credit to the original author(s) and the source, provide a link to the Creative Commons license, and indicate if changes were made.

\section{References}

Acharya S, Singh N, Katiyar AK, Maurya SB, Srivastava RB (2012) Improving soil health status of cold desert Ladakh region. Defence Institute of High Altitude Research (DIHAR), Defence Research \& Development Organisation (DRDO), Extension Bulletin No. 24, pp 1-8 
Affum AO, Osae SD, Nyarko BJB, Afful S, Fianko JR, Akiti TT, Adomako D, Acquaah SO, Dorleku M, Antoh E, Barnes F, Affum EA (2015) Total coliforms, arsenic and cadmium exposure through drinking water in the Western Region of Ghana: application of multivariate statistical technique to groundwater quality. Environ Monit Assess 187:1-23

Ahmad Z, Qadi A (2011) Source evaluation of physicochemically contaminated groundwater of Dera Ismail Khan area, Pakistan. Environ Monit Assess 175:9-21

American Public Health Association (APHA) (1998) American Water Works Association (AWWA) and Water Environment Federation (WEF). Standard methods for the examination of water and waste water. American Public Health Association, USA, 20th ed., Washington, DC

American Public Health Association (APHA) (2012) American Water Works Association (AWWA) and Water Environment Federation (WEF). Standard methods for the examination of water and waste water. American Public Health Association, USA, 20th ed., Washington, DC

Anonymous (2009) Ground Water Information Booklet of Leh District, Jammu and Kashmir State, North Western Himalayan Region, Central Ground Water Board Jammu, Unpub. Report, 16

Arshad N, Gopalakrishna GS (2009) Interpretation of water quality data by multivariate statistical tools: a study in Mysore District, Karnataka, India. Nat Environ Pollut Technol 8:657-664

Asianics Agro-Dev. International (Pvt) Ltd (2000) Tarbela Dam and related aspects of the Indus River Basin, Pakistan. A World Commission on Dams case study prepared as an input to the World Commission on Dams, Cape Town, 212

Bharti VK, Giri A, Kumar K (2017) Evaluation of physico-chemical parameters and minerals status of different water sources at high altitude. Peertechz J Environ Sci Toxicol 2:10-18

Bohlke JK, Verstraeten IM, Kraemer TF (2007) Effects of surface-water irrigation on sources, fluxes, and residence times of water, nitrate, and uranium in an alluvial aquifer. Appl Geochem 22:152-174

Boutron CF, Gorlach U, Candelone JP, Bolshov MA, Delmas RJ (1991) Decrease in anthropogenic lead, cadmium and zinc in Greenland snows since the late 1960s. Nature 353:153-156

Charan G (2013) Studies on certain essential minerals status and heavy metals presents in soil, plant, water and animal at high altitude cold arid environment. PhD thesis, JAYPEE University of Information Technology, Waknaghat, Solan, India. https://goo. $\mathrm{gl} / \mathrm{v} 7 \mathrm{xkQ} 5$

Charan G, Bharti VK, Jadhav SE, Kumar S, Acharya S, Kumar P, Gogoi D, Srivastava RB (2013) Altitudinal variations in soil physico-chemical properties at cold desert high altitude. J Soil Sci Plant Nutr 13:267-277

Child D (2006) The essentials of factor analysis, 3rd edn. Continuum International Publishing Group, New York

Datta PS, Tyagi SK (1996) Major ion chemistry of groundwater in Delhi area: chemical weathering processes and groundwater flow regime. J Geol Soc India 47:179-188

Dinka MO (2010) Analyzing the extents of Basaka lake expansion and soil and water quality status of Matahara irrigation scheme, Awash Basin (Ethiopia), Vienna, Austria, PhD dissertation, University of Natural Resources and Applied Life Sciences
Grift VDB, Broers PH, Berendrecht W, Rozemeijer J, Osté L, Griffioen J (2016) High-frequency monitoring reveals nutrient sources and transport processes in an agriculture-dominated lowland water system. Hydrol Earth Syst Sci 20:1851-1868

Helena B, Pardo R, Vega M, Barrado E, Fernandez JM, Fernandez I (2000) Temporal evolution of ground water composition in an alluvial aquifer (Pisuerga river, Spain) by principal component analysis. Water Res 34:807-816

Huang G, Sun J, Zhang Y, Chen Z, Liu F (2013) Impact of anthropogenic and natural processes on the evolution of groundwater chemistry in a rapidly urbanized coastal area, South China. Sci Total Environ 1:463-464. https://doi.org/10.1016/j.scito tenv.2013.05.078

Kumar M, Ramanathan AL, Keshari AK (2009) Understanding the extent of interactions between groundwater and surface water through major ion chemistry and multivariate statistical techniques. Hydrol Process 23:297-310

Liang J, Fang H, Hao G (2016) Effect of plant roots on soil nutrient distributions in Shanghai urban landscapes. Am J Plant Sci 7:296-305

MacConkey AT (1905) Lactose-fermenting bacteria in faeces. J Hyg (Lond) 5:333

Manivaskam A (1997) Analysis of water and wastewater. Pragati Prakashan Publications, New York

Mann SR (2002) Ladakh, then and now: cultural, ecological and political, 1st edn. Mittal Publications, New Delhi, p 277

Nelson D (2002) Natural varieties in the composition of groundwater, drinking water programme. Oregon Department of Human Services, Springfield

Reghunath R, Murthy TRS, Raghavan BR (2002) The utility of multivariate statistical techniques in hydrogeochemical studies: an example from Karnataka, India. Water Res 36:2437-2442

Sarin MM, Krishnaswami S, Dill K, Somayajulu BLK, Moore WS (1989) Major ion chemistry of the Ganga- Brahmaputra river system: weathering processes and fluxes to the Bay of Bengal. Geochim Cosmochim Acta 53:997-1009

Seiler RL, Skorupa JP, Naftz DL, Nolan BT (2003) Irrigation-induced contamination of water, sediment, and biota in the Western United States-Synthesis of Data from the National Irrigation Water Quality Program

Singh D, Chhonkar PK, Dwivedi BS (2005) Manual on soil, plant and water analysis. Westville Publishing House, New Delhi, p 200

State of Environment Report, J\&K (2012-2013) Department of ecology environment and remote sensing. http://jkenvis.nic.in/water _resources_introduction.html

Varrol M, Sen B (2009) Assessment of surface water quality using multivariate statistical techniques; a case study of Behrimaz Stream Turkey. Environ Monit Assess 159:543-553

Water Quality-Sampling-Part 11. Guidance on sampling of ground waters, ISO 5667-11: 1992 (E)

Water stewardship information series. Total, fecal \& E. coli bacteria in groundwater. 2007.1-2

Publisher's Note Springer Nature remains neutral with regard to jurisdictional claims in published maps and institutional affiliations. 